$\begin{array}{cc}\text { Türk Coğrafya Dergisi } & \text { Turkish Geographical Review } \\ \text { Basıli ISSN 1302-5856 } & \text { wwitcd.org.tr }\end{array}$

\title{
Turizmin geleceğini COVID-19 mu inşa ediyor?
}

\section{Is COVID-19 building the future of tourism?}

\author{
Bekir Derinöz a* \\ ${ }^{a}$ Balıkesir Üniversitesi, Fen-Edebiyat Fakültesi, Coğrafya Bölümü, Balıkesir, Türkiye.
}

ORCID: B.D. 0000-0002-0427-2092

\begin{tabular}{l} 
BILGi / INFO \\
\hline Geliş/Received: 25.09 .2021 \\
Kabul/Accepted: 25.12.2021 \\
\hline Anahtar Kelimeler: \\
Turizm \\
Covid-19 \\
Turizmde değişim-dönüşüm \\
Pandemi \\
Keywords: \\
Tourism \\
Covid-19 \\
Change-transformation in tourism \\
Pandemic
\end{tabular}

Pandemic

*Sorumlu yazar/Corresponding author:

(B. Derinöz)

bekirderinoz@balikesir.edu.tr

DOI: $10.17211 /$ tcd. 1000764

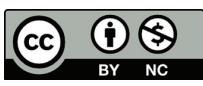

\section{Atif/Citation}

Derinöz, B. (2021). Turizmin geleceğini COVID-19 mu inşa ediyor? Türk Coğrafya Dergisi, (79), 41-50.

https://doi.org/10.17211/tcd.1000764

\begin{abstract}
ÖZ / ABSTRACT
2020 yııında uluslararası turizm büyümesinin \% 75 civarında azaldığı bilinmektedir. Bu azalma turizm sektörünü pandemiden en çok etkilenen sektörlerden biri haline getirmiştir. Bu çalışmanın amacı Covid-19 pandemisinin turizmi nasıl etkilediği, bu etkinin turizmde ne tür değişim ya da dönüşümlere neden olduğu ve gelecekte pandeminin nasıl bir turizm yaklaşımı/yaklaşımları inşa edeceğini araştırmaktır. Bu amaçla araştırma kapsamında belirlenen araştırma soruları: Covid-19 pandemisinin turizmdeki temel etkisi nedir? Pandemi turizmde hangi değişim ve dönüşümlere neden olmuştur? Başta turizm destinasyonları olmak üzere gelecekte turizmin temel dinamikleri pandeminin etkisiyle neye/nereye doğru evrilecektir? Pandemi turizm için firsat mıdır, yoksa tehdit midir? Araştırmada nitel araştırma yöntemlerinden literatür taraması ve doküman analizi yöntemleri kullanılmıştır. Araştırma sonuçları dünya açısından önemli bir endüstri olan turizmin temelde pandemiden ağır şekilde etkilendiğini göstermektedir. Bu etki özellikle 2020 yılı başından itibaren kendini hissettirmeye başlamış, pandeminin yaygınlaşmasıyla beraber turizm faaliyetlerindeki düşüş hızlanmış, kriz de derinleşmiştir. Sonraki süreçte turizmin gelişimini pandeminin dünyadaki seyri belirlemiştir. Ülkeler gelecekte turizmde pandeminin etkilerini en aza indirebilmek için yeni yol ve yöntemler geliştirme çabasına girişmişlerdir. Bu kapsamda özellikle iç turizm destinasyonlarına ağırlık verilmekte, kitle turizmi terkedilmekte, özel sürdürülebilir turizm yaklaşımları ön plana çıkmakta ve turizm bireyselleşmektedir.
\end{abstract}

It is known that international tourism growth has decreased by $75 \%$ in 2020 . This decrease has made the tourism sector one of the sectors most affected by the pandemic. The aim of this study is to investigate how the Covid-19 pandemic affects tourism, what kind of changes or transformations this effect causes in tourism, and what kind of tourism approach(s) the pandemic will build in the future. For this purpose, the research questions determined within the scope of the research: What is the main effect of the Covid-19 pandemic on tourism? What changes and transformations has the pandemic caused in tourism? What/where will the basic dynamics of tourism, especially tourism destinations, evolve with the effect of the pandemic? Is the pandemic an opportunity or a threat for tourism? In the research, literature review and document analysis methods from qualitative research methods were used. The results of the research show that tourism, which is an important industry for the world, has been heavily affected by the pandemic. This effect has started to make itself felt especially since the beginning of 2020, with the spread of the pandemic, the decline in tourism activities has accelerated and the crisis has deepened. In the next period, the development of tourism was determined by the course of the pandemic in the world. Countries have tried to develop new ways and methods in order to minimize the effects of the pandemic in tourism in the future. In this context, especially domestic tourism destinations are emphasized, mass tourism is abandoned, special sustainable tourism approaches come to the fore and tourism becomes individualized. 
Extended Abstract Introduction

The tourism sector shows a constantly and rapidly growing feature around the world. The sector is also an important employment area for the countries of the world and it is known that approximately one out of every 10 people is employed in the tourism sector. However, the growth in tourism has been hit hard by the covid-19 pandemic that emerged in 2020. As a matter of fact, it is stated that international tourism growth decreased by about 75\% according to the records in 2020 . This decrease has made the tourism sector one of the sectors most affected by the pandemic. World governments have taken some decisions to reduce this effect of the pandemic in tourism, but the effectiveness of these decisions will be seen more clearly in the future.

\section{Data, Purpose and Method}

The aim of this study is to investigate how the covid-19 pandemic, which emerged in March 2020, affects tourism, what kind of changes or transformations this effect has witnessed in tourism, and what kind of tourism approach(s) will the pandemic build in the future. For this purpose, the research questions determined within the scope of the research: What is the main effect of the Covid-19 pandemic on tourism? What changes and transformations has the pandemic witnessed in tourism? What/where will the basic dynamics of tourism, especially tourism destinations, evolve with the effect of the pandemic? Is the pandemic a good opportunity or a threat for tourism? In the study, literature review and document analysis methods, which are qualitative research methods, were used. The basic data of the research consists of 20 scientific resources, consisting of articles and books, on the relevant subject. In this study, evaluations and interpretations were made on the results of these sources, and suggestions were made by reaching new results.

\section{Results, Recommendations and Discussion}

The results of the research show that tourism, which is an important livelihood sector for the world, has been heavily affected and damaged by the pandemic. This effect started to show itself especially from the beginning of 2020, and with the spread of the pandemic, it caused significant decreases in participation in tourism activities. The increase in the course of the pandemic worldwide has accelerated and deepened the decline in tourism. Today, the pandemic still continues to affect tourism. This effect has been tried to be partially reduced by the governments' emphasis on domestic tourism and various tourism plans around the world. However, these studies were not sufficient. Within the scope of the urgent measures taken, cash supports were provided to the sector by the governments in some countries, and tourism enterprises were tried to be protected. In some countries, the pandemic has been evaluated as an opportunity for green and sustainable tourism, and practices and policies that can be effective and permanent in the future have begun to be determined in this direction.

Many international tourism destinations, especially mass tourism centers, have been significantly affected by the situation, and the demand and pressure on rural areas has increased during the pandemic period. This pressure has also changed the direction of tourism destinations, and natural areas have started to turn into tourism destinations gradually. This is an important situation that needs to be investigated on its own. With the successful conclusion of the vaccination studies, there has been a slow movement especially in domestic tourism, but sufficient revival has not been achieved yet. The restoration of tourism is closely related to the establishment of a climate of trust at the international level. Because tourists can only start participating in tourism when they feel safe. In this process, supporting domestic tourism movements can be considered as the initial studies for the global tourism to stand up. However, this is not enough. Cooperation between countries will also contribute to tourism.

It is seen that there are serious changes in tourism destinations with the pandemic. The places where the pandemic has affected tourism the most in the world have been the AsiaPacific region and the Americas. It is stated that tourism losses caused by air transportation alone exceed 80 billion dollars. This pandemic crisis has brought along multifaceted inquiries in tourism. In particular, international mass tourism destinations have been the areas most affected by this crisis. These areas have rapidly lost value, billions of dollars of damage have occurred, and there has been an explosion in the demand for rural areas and services. In addition, in the 21st century, when the concept of sustainability is questioned, sustainable tourism and green tourism approaches have begun to be reconsidered. At this point, could the aforementioned global crisis be a good opportunity to think and plan the future of tourism? Of course it can. World tourism actors have statements supporting this. The measures taken/to be taken by the tourism actors and governments today undoubtedly have an important role in the construction of the tourism of the future. In this process, the fact that there will be a pandemic in tourism in the next period should be accepted and short, medium and long-term tourism policies should be determined in this direction. The current crisis should be an instructive and reminder for policies and approaches in tourism to be more robust, sustainable and flexible.

The impact of the pandemic on tourism has not yet been fully revealed. However, considering the end of the pandemic, it is thought that it will be more important to protect the environment and provide local employment in tourism. In this period, tourism and locality will continue to exist as two important elements and the structuring of tourism will develop more strongly in this axis. It is predicted that ecotourism, which is one of the tourism strategies, will become dominant and new niches and destinations will emerge in tourism. At the point of receiving contactless service, it is possible that technology will find more place in tourism and tourism investments that include digital technologies will be made. One of the most important points is that after possible changes in tourist preferences and behaviors, the economic structure of some countries, which is fully based on tourism, will be affected and these countries will have to explore new areas different from or alongside tourism in order to maintain their economic existence. This means that these countries will have to invest in other sectors other than tourism. As a result, it will take time for tourism to return to its bright and vibrant days, but this situation is closely related not only to 
the pandemic but also to international developments. In the upcoming period, countries will continue to try new ways and methods in tourism in order to minimize the effects of the pandemic in tourism on a global scale.

\section{Giriş}

Turizm endüstrisi geçmişten günümüze dünya üzerinde milyonlarca insana geçim kaynağı sağlamaktadır. Bunun yanı sıra turizm yeryüzünde milyarlarca insana hem kendi kültürlerini tanıtma, hem de farklı kültürler tanıma imkanı sunmaktadır. Turizm dünyada bazı ülkeler açısından hayati öneme sahiptir. Nitekim bu ülkelerin gayri safi yurt içi hasılalarının \% 25'e yakını turizm sektöründen sağlanmaktadır. Bunun yanı sıra turizm dünya ekonomisinin en büyük ilk 3 sektörü arasında yer almaktadır. Turizm sektörü ortaya çıkan kriz durumlarında çok çabuk etkilenen, ani tepkiler verebilen dinamik bir yapıya sahiptir (Blake \& Sinclair, 2003; Acar, 2020; Çetin \& Göktepe, 2021; Hudson, 2020).

2020 yılı mart ayı başlarında tüm dünyada etkisi hissedilmeye başlanan Covid 19 pandemisi dünya üzerinde hemen her kıtada turizmle birlikte birçok sektörü derinden etkilemiştir. Turizm bu dönemde bir güven problemi yaşamıştır. Nitekim pandemi gibi aniden ortaya çıkan beklenmedik durumlar ve olaylar ortaya çıktı̆ı turizm destinasyonlarında destinasyona var olan güveni azaltmaktadır (Çeti \& Ünlüören, 2019; Karakaş, 2020; Seyfi, Hall \& Shabani, 2020). Sektörde azalan güven insanların turizme katılmamasına yol açmış, ülkeler bu durumdan dalga dalga etkilenir hale gelmiştir. Covid 19 pandemisinin etkilerini her ülke aynı oranda hissetmemiştir. Ancak pandemiden zarar görmeyen hiçbir ülke neredeyse kalmamıştır. En başta da ekonomisinin turizme bağlı olduğu ülkeler ciddi zararlar görmüşlerdir. Bunların birçoğu da gelişmekte olan ülkeler ve gelişmemiş ülkelerdir. Bu ülkeler dahil olmak üzere dünya genelinde turizmde özellikle konaklama sektöründe ekonomik, sosyal ve psikolojik sıkıntılar baş göstermiştir (Gürsoy, Sarışık vd., 2021). Karalardan uzak izole bir coğrafyada bulunan Yeni Zelanda'da dahi hizmet sektöründe Covid 19 kaynaklı zararlar kaydedilmiştir (Hall vd., 2020).

Pandemiyle beraber ortaya çıkan sağlık ve ekonomi krizleri hükümetleri nüfuslarını korumak için önlemler almaya itmiş, bu önlemler kapsamında son derece kat kısıtlamalar ve sokağa çıkma yasakları hemen her ülkede uzunca bir süre uygulanmıştır. Bu nedenle iç hareketlilikle beraber ülkeler arasındaki hareketlilik de durmuş, havayolu taşımacılığı askıya alınmıştır. Çünkü büyük nüfus kitleleri ülkeler arasında hava yolu ulaşımı sayesinde yer değiştirmektedir. Salgının yayılımını durdurmak havayolu ulaşımını da durdurmayı gerekli kılmıştır. Yaşanan bu ani kriz özellikle turizm sektöründe son dönemlerde görülmemiş bir daralmaya neden olmuştur (Findlater \& Bogoch, 2018; Kervankıran \& Bağmancı, 2020). Dünyanın en gelişmiş ekonomisine sahip olduğu bilinen ABD'nin dahi Covid 19 ile mücadele kapsamında benimsediği önlemler, özellikle konaklama endüstrisinin getirilerinde önemli düşüşlere neden olmuştur. Yine $A B D$ 'de konaklama ile ilişkili eğlence ve ulaşım gibi diğer sektörlerde de benzer durumlar yaşanmıştır. Covid 19 ABD için 11 Eylül'den sonra yaşadığı en önemli ikinci tarihi kriz haline gelmiştir (Aharon, Arie and vd., 2021).
Yaşanan gelişmeler neticesinde dünya ülkeleri zarara uğrayan ve bozulan ekonomilerini düzeltmek için yeni arayışlar içerisine girmiş, turizm dahil olmak üzere tüm ekonomik sektörlerde bir güncelleme ihtiyacı hissetmişlerdir. Bu süreçte tüm ülkeler açısından başta turizm ve turizmle ilişkili olan birçok sektörün korunması ülkelerin önceliği haline gelmiştir. Turizm sektöründe bu korumayla beraber sektör yeniden inşa sürecine girmiştir. Bu inşa sürecinde yeni destinasyonlar, yeni turizm yaklaşımları, turizmde ülke ortaklıkları ve sürdürülebilirlik ana temaları üzerinde durulmuştur.

\section{Amaç, Araştırma Soruları ve Yöntem}

Yapılan çalışmanın amacı 2020 yılı mart ayında ortaya çıkan Covid-19 pandemisinin turizmi nasıl etkilediği, bu etkinin turizmde ne tür değişim ya da dönüşümlere neden olduğu ve gelecekte pandeminin nasıl bir turizm yaklaşımı / yaklaşımları inşa edeceğini araştırmaktır. Bu amaçla araştırma kapsamında belirlenen araştırma soruları:

$>$ Covid-19 pandemisinin turizmdeki temel etkisi nedir?

$>\quad$ Pandemi turizmde hangi değişim ve dönüşümlere neden olmuştur?

$>$ Başta turizm destinasyonları olmak üzere gelecekte turizmin temel dinamikleri pandeminin etkisiyle neye/nereye doğru evrilecektir?

$>$ Pandemi turizm için iyi bir firsat mıdır, yoksa tehdit midir?

Belirlenen araştırma sorularını cevaplamak amacıyla çalışma kapsamında nitel araştırma yöntemlerinden olan literatür taraması ve doküman analizi yöntemleri kullanılmıştır. Araştırmada bilimsel makale ve kitaplardan oluşan 20 yayın incelenmiş ve bu yayınlardan elde edilen veriler karşılaştırmalı olarak yorumlanmış ve yeni değerlendirmeler yapılarak turizmin geleceğine dair öneriler sunulmuştur.

\section{Literatür Özeti}

Covid-19 literatürü incelendiğinde literatürde genel olarak turizm Covid-19'dan en önemli derecede etkilenen anahtar sektör olarak tanımlanmaktadır (Lew vd., 2021). Yapılan çalışmalarda daha ziyade turizm sektörüyle ilgili olarak tüm ülkelerin gelişmesi ve kalkınması noktasında sektörün önemi vurgulanmaktadır. Yine yapılan çalışmalar Covid-19 pandemisinin turizmde büyük risk oluşturduğu fikri üzerinde birleşmişlerdir (Hudson, 2020).

Aharon, Arie, Cohen ve diğerleri (2021) ABD hükümeti tarafindan Covid-19 ile mücadele için kabul edilen kamu önlemleri ile Amerikan konaklama endüstrisinin performansı arasındaki etkileşimi araştırmışlardır. Araştırmaları sonucunda hükümet müdahalelerinin çoğunun, konaklama endüstrisinin getirilerinde olumsuz bir tepkiyle ilişkili olduğunu tespit etmişlerdir. Covid-19 pandemisinin ilerledikçe daha olumsuz yanıtlar geliştirdiğini; konaklama ile yakından ilişkili eğlence ve ulaşım gibi diğer endüstriler için de benzer nitelikte modeller tespit edildiğini ifade etmişlerdir. 
Acar (2020) Covid-19 salgınının turizm faaliyetleri üzerindeki güncel ve gelecek dönemlerdeki muhtemel etkilerini tespit etmeyi amaçladığı çalışmasının sonucunda yeni koronavirüsün ülke ekonomilerindeki etkilerinin uzun süre hissedilebilecek türden zararlar oluşturacağını ve turizm sektörünün de bu zararlardan doğrudan olumsuz bir şekilde etkileneceğini ifade etmektedir. Yine aynı amaçla yapılan bir diğer çalışmada Çetin ve Göktepe (2021) salgının hızla gelişerek turizm sektörünü tüm dünyada derinden etkilediğini, turizmde herhangi bir zamanda ortaya çıkabilecek yeni bir pandemi dalgasına dair senaryolar oluşturulduğunu, bu senaryoların dahi turizme zarar verdiğini, salgın tamamen ortadan kalksa bile turizme verdiği zararın kalıcı değişimlere yol açacağını, turizmde daha ziyade iç turizm hareketlerinin canlanacağını ve bireysel turizm yaklaşımlarının ön planda olacağını ve turizm sektörünün bir süre daha pandemiden kaynaklanan etkilere maruz kalacağını ifade etmişlerdir.

Gürsoy ve diğerleri (2021) tarafindan Covid-19 pandemisinin turizm ve konaklama endüstrisi üzerindeki etkilerine dair kapsamlı bir araştırma yapılmıştır. Araştırmada konu ekonomik, sosyolojik ve psikolojik perspektiflerden tartışımıştır. Araştırmada kritik vaka çalışmaları, hem sektöre dahil olan bireyler üzerindeki mikro etkileri hem de pandeminin daha geniş olarak ortaya çıkardığı sorunlara hükümet ve uluslararası tepkileri araştırmak için kullanılmıştır. Çalışmanın bölümlerinde turizm ve konaklama organizasyonlarının destinasyon markalaşması da dahil olmak üzere pazarlama stratejileri ve yeniden düşünülmesi gereken yollar üzerinde durulmuştur. Ayrıca bu çalışmada önceki pandemilerin turizm sektörü üzerindeki etkisine ve bunun gelecekteki uygulamaları nasıl yönlendirebileceğine değinilmiş; bu konuda detaylı bilgiler verilmiş ve pandeminin ekonomik etkileri analiz edilmiştir. ilgili çalışma Covid-19'un turizm işgücünü, turizm çalışanlarının psikolojisini, tedarik zincirlerini ve gelirleri nasıl etkilediğine bakarak turizm yönetimi için gerekli olabilecek değişiklikleri vurgulaması açısından önemlidir. Bu çalışma turizm çalışmaları ile işletme ve yönetim alanında çalışan bilim insanları için eleştirel bir okuma niteliğindedir. Bunun yanı sıra çalışma Covid-19 pandemisine nasıl tepki verileceğini daha iyi anlamak isteyen turizm ve konaklama endüstrisindeki yönetim kadrosu için de yararlı bir kaynak niteliğindedir.

Hall ve diğerleri (2020) tüketicilerin alıştkkları mal, hizmet ve kolaylıklarda harici bir olay sonucunda bir değişiklik yaşadığında meydana gelecek olan mekânsal ve zamansal kaymayı; bu kayma sonucunda tüketimin nasıl yer değiştireceğini Yeni Zelanda örneğinde değerlendirmişlerdir. Araştırma sonucunda tüketici harcama modellerine dayalı olarak tüketimin mekânsal ve zamansal yer değiştirmesine dair kanıtlar sunulmuştur. Çalışmaya göre bazı tüketim kategorilerinde artan harcama kanıt, stoklama davranışlarını doğrulamaktadır ve konaklama sektörünün, tecrit nedeniyle tüketici harcamalarında keskin bir düşüş yaşadığı görülmüştür.

Higgins-Desbiolles (2020) çalışmasında Covid-19 salgınının, turizm endüstrisini ve faaliyet gösterdiği bağlamı dönüştürme potansiyeline sahip olduğunu ifade etmiştir. Ona göre dünyanın birçok yerinde seyahat, turizm, konaklama ve etkinliklerin durdurulmasıyla ortaya çıkan bu küresel kriz, tarihi bir dönüştürücü olarak anlık olasılıkları ortaya çıkarmak için bir firsat sunmaktadır. Covid-19 pandemisinin neden olduğu kriz, turizmi gelecek için daha iyi bir yola doğru yeniden düşünmek ve sıfirlamak için nadir ve paha biçilmez bir firsat sunabilir. Bununla birlikte, turizme yönelik sorumlu yaklaşımlar tek başına böyle bir sıfirlamayı sağlamak için yeterli kapasite sunmayacaktır. Bunun yerine, böyle bir vizyon, yerel toplulukların ve yerel halkların haklarına ve çıkarlarına dayalı olarak turizmi yeniden tanımlayan ve yeniden yönlendiren toplum merkezli bir turizm çerçevesi gerektirir. Teorik olarak böyle bir yaklaşım, turizmin kamu yararına odaklanarak "sosyalleştirilebileceği" bir yolu içerir. Bu, turizmin gezegenin sosyal ve ekolojik sınırlarına karşı sorumlu kılınması için gereklidir.

Hudson (2020) Covid-19'un turizm sektörüne kötü bir darbe indirdiğini, salgın nedeniyle UNWTO'ya göre 2020'de uluslararası turist varışlarının dünya çapında \%74 düştüğünü ve milyonlarca insanın işsiz kaldığını, bundan sonraki süreçte endüstrinin yavaş yavaş toparlanacağını ancak seyahatin bir daha asla eskisi gibi olmayacağını ifade etmektedir. Hudson çalışmasında Covid-19 krizinin nasıl ortaya çıktığını ve seyahat, turizm ve konaklama sektörleri üzerindeki yıkıcı etkilerini incelemiştir. Uluslararası vaka çalışmalarıyla dolu olan araştırmasında krizin en başından başlayarak sektörün nasıl tepki verdiğini incelemiş ve krizin piyasaya verdiği mesaj ile ortaya çıkan etkilerine ve olası bir geleceğe kadar değinmiştir. Araştirmada Covid-19 salgını ve seyahatin neden ayrılmaz bir şekilde bağlantılı olduğu, sektörün farklı alt sektörlerinin krize nasıl uyum sağladığı, krize yanıt olarak kuruluşların kullandığı kriz iletişim stratejilerinin neler olduğu, gezginlerin krizden nasıl etkilendikleri, pandeminin sosyal, ekonomik ve çevresel etkileri ile Covid-19 sonrası seyahatin geleceği üzerinde yoğunlaşılmıştır.

Lew ve diğerleri (2021) Covid-19 pandemisinin seyahat ve turizmi küresel olarak nasıl dönüştürdüğüne odaklanmışlardır. Araştırmacılar yaptıkları çalışmada Covid-19'un neden olduğu yıkıma rağmen, devam eden krizde turizm sektörünü turizm uygulayıcıları, turistler ve ev sahibi topluluklar için daha umutlu bir geleceğe katkıda bulunacak şekilde olumlu bir hale dönüştürme firsatı olduğunu savunmuşlardır. Onlara göre dünya Covid-19'un gölgesinden çıkarken normale dönüş olmayacaktır. Daha ziyade kısmen Covid-19 sonrası dönemde insanların seyahat etme, birbirleriyle ve çevreleriyle karşılaşma biçimlerinin değişmesiyle yönlendirilen bir küresel dönüşüm vizyonunun sağlanması söz konusudur.

\section{Bulgular}

\subsection{Covid-19 Pandemisinin Turizmdeki Temel Etkileri}

Turistlerin ülke içinde ya da ülkeler arasındaki seyahatleri birçok faktör tarafindan etkilenebilir. Bu faktörler arasında pandemiler gerçekleştiği dönemlerde az ya da çok turizm faaliyetlerini etkilemişlerdir. Pandemilerin ortaya çıkardığı güven sorunu turizmin önündeki en büyük engel olarak görülmektedir. Güvensizlik ziyaretçilerin algılarına da yansımakta ve böylece bazı destinasyonlar "güvensiz yerler" olarak değerlendirilmektedir. Dünya tarihinde bu doğrultuda bazı krizler yaşanmıştır. Bunlar arasında SARS, MERS, Ebola, İspanyol Gribi gibi bazı salgınlar örnek olarak gösterilebilir. Ancak Covid 19 bunlardan daha derin bir krize neden olmuştur. Şöyle ki Dünya Turizm Örgütü (UNWTO) verilerine göre 2019 yılı sonunda dünya ticaretinin yaklaşık \% 8'ini turizm sektörü oluşturmuştur (WTO, 2020). 
Turizm pandemiden önce ciddi oranda istihdam yaratan, birçok sektörle ilişkili, oluşturduğu değerler zinciri ile milyonlarca insanın geçimini sağlayan bir sektör durumunda idi. Ancak pandemiyle beraber ilk değişim ülke içinde ve dışında hareketliliğin durması ile meydana geldi. Bu hareket kısıtlılığı sonucu ilk olarak ülke sınırları kapatılmıştır. Bunu otellerin ve diğer turizm tesislerinin kapatılması süreci izlemiştir. Takip eden süreçte hava ulaşımı tamamen durma noktasına gelmiştir. Bunun sonucunda kayıtlara göre uluslararası turizm seyahatleri yaklaşık \% 60 oranında azalmıştır. Bu durum dünyadaki birçok ülkede olduğu gibi Türkiye'de de etkisini göstermiş, sektör 2009 krizine oranla 3 kattan daha fazla değer kaybetmiştir. Türkiye'de 2020 yılında gelen turist sayısındaki ciddi düşüş ile birlikte uluslararası turizm büyümesinin kayıtlara göre \% 74 oranında tarihi şekilde azaldığı kaydedilmiştir (Şekil 1).

Turizm sektörünün durdurulamayan değer kaybı hükümetlerin ödemeler dengesini de etkilemiş; diğer sosyal, ekonomik ve kültürel kamu hizmetleri finanse edilemez hale gelmiştir. Çünkü turizm ülkeler için önemli bir finans kaynağıdır. Bazı hesaplamalara göre bu dönemde turist harcamaları 2019 yılına oranla 600 milyon dolar kadar azalmış ve turizmden geçimini sağlayan yaklaşık 100 milyon insan bu krizden etkilenmiştir. Bunların büyük kısmı da genç istihdam ve kayıt dışı çalışanlar olmuştur (UNCTAD, 2021; Çetin \& Göktepe, 2021). Ekonomisi pandemiden olumsuz etkilenmeyen hiçbir ülke neredeyse kalmamıştır (UNCTAD, 2021; WTO, 2020).

Covid 19 pandemisinin turizm sektörünü vurması beraberinde başka sorunları da getirmiştir. Dünya ülkelerinde (özellikle gelişmekte olan ve gelişmemiş ülkelerde) yoksulluk artmış, toplumsal ekonomik eşitsizlik büyümüştür. Bu durum sürdürülebilir kalkınma hedeflerinde de ciddi aksamalara neden olmuş; üretim, tüketim ve ekonomik büyüme yavaşlamıştır. Kırsal alanlarda turizmin yerel halk için barındırdığı hayati önem pandemiyle beraber azalınca hizmet sunumu, gelir üretimi ve kırsal ekonomik büyüme de azalmıştr. Özellikle Afrika kıtasında yer alan bazı ülkelerde olduğu gibi kadınların istihdamına katkı sağlayan turizmin zayıflaması turizmde cinsiyet eşitsizliklerini de beraberinde getirmiştir (Rogerson \& Rogerson, 2020; WTO, 2020).

Turizmin doğal ve kültürel kaynak değerlerini ziyaret etmeye dayanan yapısı aynı zamanda turistler için de bir motivasyon kaynağıdır. Bu alanlardan birçoğu halihazırda koruma altında bulunan alanlardan ibarettir. Pandeminin neden olduğu turizm krizi söz konusu korunan alanların etrafinda yaşayan yerel halkın geçim kaynaklarında da ciddi kayıplara yol açmıştr. Korunan alanlarla beraber özellikle yaban hayat turizminin geliştiği diğer alanlar ve biyoçeşitlilik koruma sahaları bu durumdan etkilenmiştir (Newsome, 2020). Burada başka bir sorun daha ortaya çıkmıştır. Korunan alanların etrafinda yaşayan yerel halk bu ani gelişen küresel kriz sonucu kısa zamanda kendisine alternatif turizm alanları ya da faaliyetleri geliştirememiş, bunun sonucunda uğradığı zararı telafi etmek için doğal kaynaklara daha fazla baskı yapmaya başlamıştır. Bu daha önceden karşılaşılmamış, yeni bir sorundur.

Turizm sektörünün ana ayaklarından biri olan kültürel kaynaklar küresel ölçekte turizmin en önemli çekiciliklerinden birini oluşturmaktadır. Pandemi kültürel mirasın korunması konusunda da etkisini hissettirmiştir. Buna ilk örnek olarak yerli halklar ve küçük geleneksel topluluklar verilebilir. Bu tür topluluklarda pandemi nedeniyle el sanatlarının yanı sıra sunulan yerel ürün ve pazar hizmetleri durmuş, özellikle bununla geçimini sağlayan kadınların gelirleri azalmıştır. Bununla beraber ikinci örnek olarak antik yerleşimler, müze, sit alanları ve çeşitli mimari yapılardan oluşan kültürel turizm kaynakları verilebilir. Bu kaynaklar da pandemi nedeniyle kullanılamaz hale gelmiştir. Kayıtlara göre pandemi döneminde dünya üzerindeki ülkelerin yaklaşık \% 92'si kültürel turizm kaynak değerlerini belirli bir dönem kapatmak durumunda kalmıştır (Prideaux vd., 2020). Bu yönde gelişmekte olan ülkelerdeki turist girişleri önemli oranda azalmıştır (Şekil 2). Bu durum pandeminin vurucu etkisini açıkça göstermektedir.

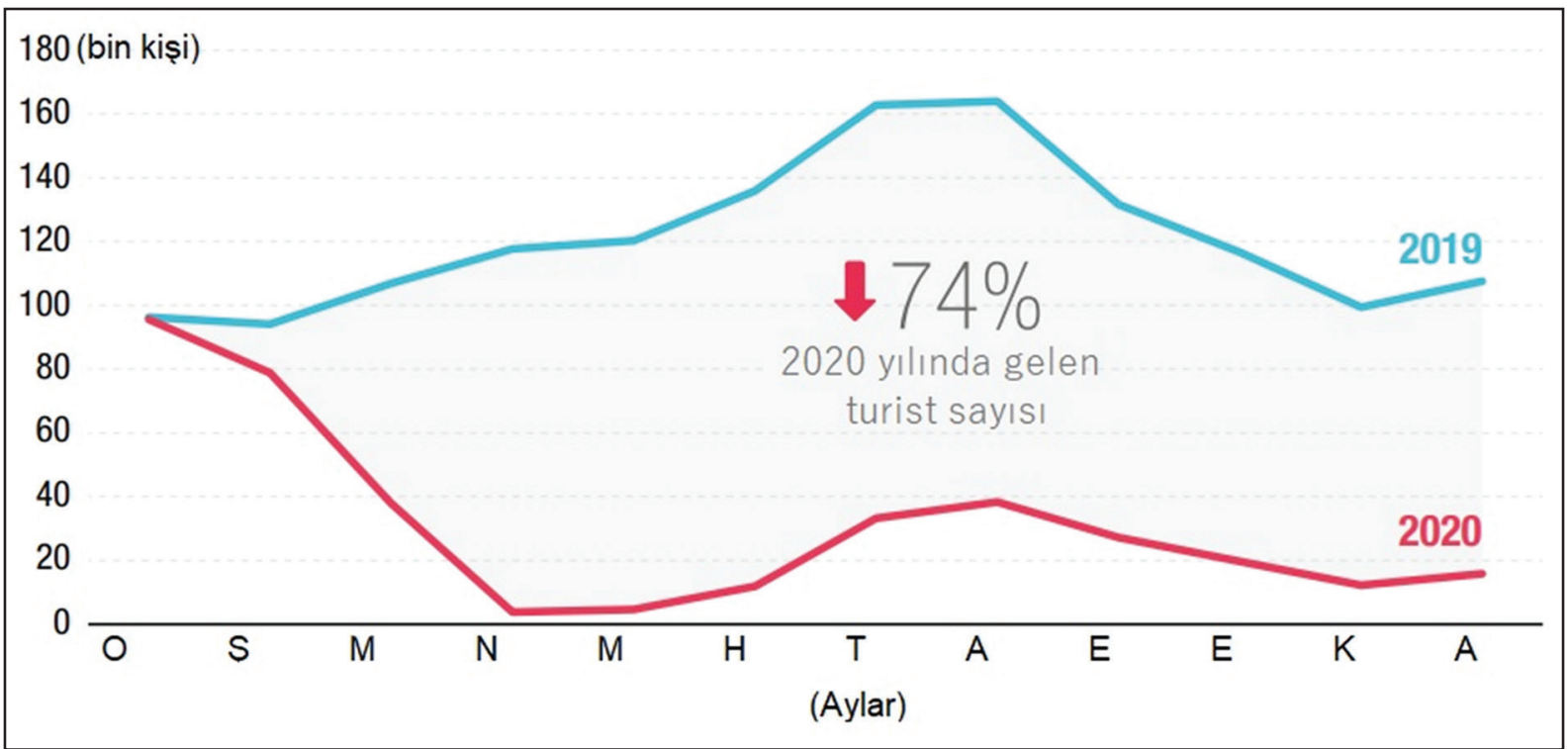

Şekil 1. Türkiye'de 2019-2020 yıllarında pandemi nedeniyle gelen turist sayısındaki değişim (Kaynak: UNCTAD, 2021'den değiştirilerek). Figure 1. Change in the number of tourists arriving in Turkey due to the pandemic in 2019-2020 (Source: Modified from UNCTAD, 2021). 


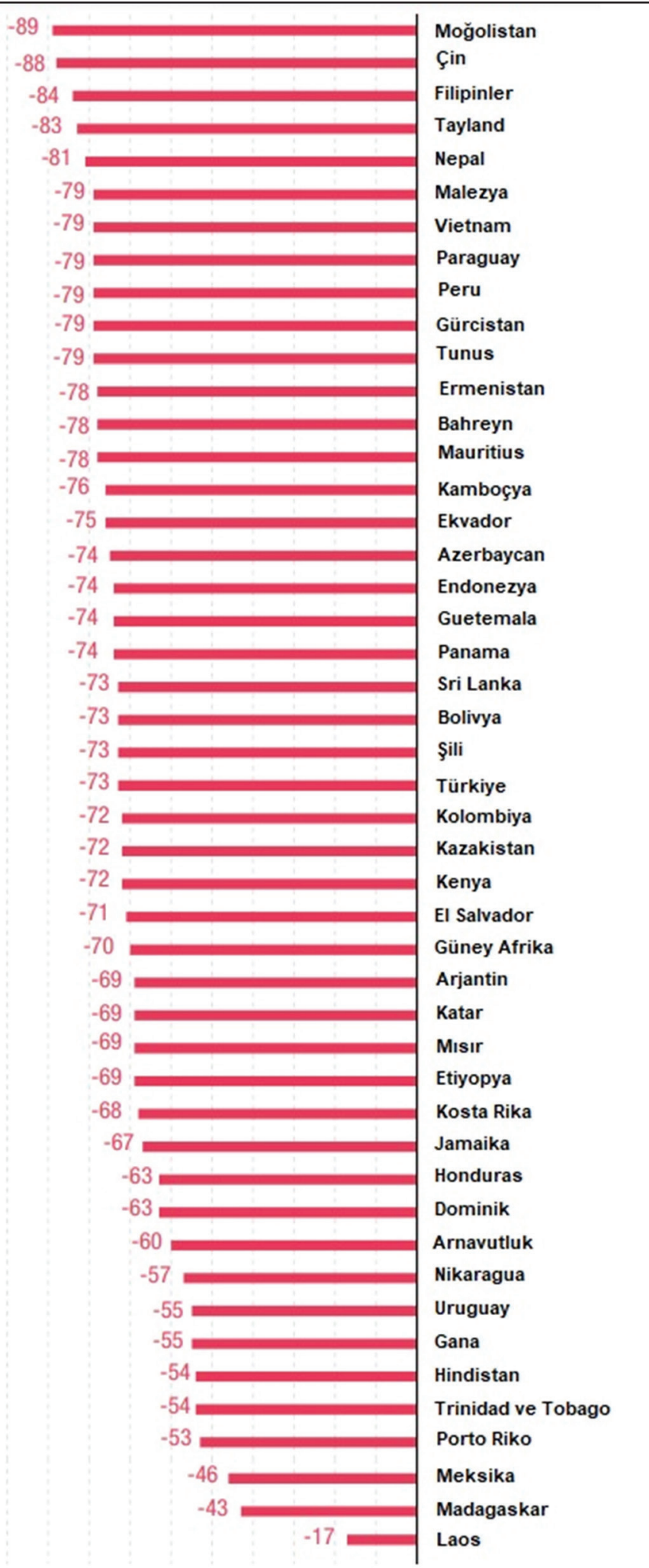

Şekil 2. Gelişmekte olan bazı ülkelerde 2020 yılında turist girişlerindeki azalma (Kaynak: UNCTAD, 2021'den değiştirilerek).

Figure 2. Decrease in tourist arrivals in 2020 in some developing countries (Source: Modified from UNCTAD, 2021).

\subsection{Pandemi Turizmde Neleri Değiştirdi?}

Turizm temelleri doğa üzerine kurulu büyük ve yaygın bir endüstridir. Dolayısıyla turizm sektörünün doğadan bağımsız olması düşünülemez. Geleneksel olarak geçmişten günümüze turizm algısı dünya genelinde kıyı turizmi (geleneksel ya da kitle turizmi olarak da bilinir) olarak bilinen ve deniz-kum-güneş (3 S, Sea-Sand-Sun) ile ifade edilen turizm üzerinde yo- ğunlaşmıştır. Bu turizm modeli orta (ılıman) kuşak ülkelerinin deniz ya da okyanus kıyılarında kitle turizmi şeklinde yapılagelmiştir. Ayrıca kitle turizminin kesintisiz olarak son 2 asırdan beri sürekli arttı̆ı bilinmektedir. Covid 19 bu artışı neredeyse tamamen durdurmuştur. Bu tarihte neredeyse eşi benzeri görülmemiş bir gelişme olarak karşımıza çıkmaktadır. Ve bu şok dalgası ülke ekonomilerinde önemli düşüşleri beraberinde getirmiştir (Şekil 3).

Pandemiyle beraber ülkeler çeşitli önlemler alma çabasına girmişlerdir. Pandeminin kontrol altına alınması için ilk önlem olarak seyahat kısıtlamaları ve izolasyon tedbirlerinin devreye sokulması turizmi derinden etkilemiştir. Dünyada uygulanan kısıtlama önlemleri zamanla gönüllü ya da zorunlu önlemlere dönüşmüş ve gerek ülkeler arasında, gerekse de ülke içinde seyahat tamamen durmuştur. Bu durgun dönem turizm endüstrisinde ciddi bir kriz yaratmış, bu kriz vaka sayılarındaki belirgin düşüşe kadar ciddi derecede etkili olmuştur. Vaka sayılarındaki düşüşle beraber seyahat kısıtlamalarının kısmen kaldırılması ve alınan diğer önlemlerin esnetilmesi sonucunda sektör yavaş yavaş yeniden bir toparlanma sürecine doğru girmiştir.

Covid 19 ile beraber küresel ölçekte dünya yeni bir bağlam kazanmıştır. Bu yeni küresel bağlamda turizmde kitlesellik terkedilmeye başlanmış, bireysellik ve sürdürülebilirlik önem kazanmış, ciddi şekilde zarar görmüş olan turizmin toparlanması ve yeniden inşa edilmesi yönünde kararlar alınması gerektiği ortaya çıkmıştır. Bu kapsamda her geçen gün dünyada turizmin dönüştürülmesi için yeni ve güvenli rota oluşturma çabaları devam etmektedir. Bu çabalar ekoturizm, macera turizmi, seyahat balonları, yeşil turizm gibi çeşitli turizm yaklaşımları ve araçları ile sürdürülebilir turizmi desteklemek için farklı stratejiler sunmaktadır (Higgins-Desbiolles, 2020; Fuste-Forne \& Michael, 2021). Bu stratejiler bir bakıma turizmin jokeri olup, en kritik dönemlerde kurtarıcı durumundadırlar.

\subsection{Pandemi Turizmin Geleceğini Nasıl Etkiler?}

Turizm endüstrisinde turistlerin davranışlarını etkileyen birçok faktör bulunmaktadır. Seyahat etme motivasyonu destinasyonun doğal ve fiziksel koşulları ile yakından ilgilidir. Bunun gibi politik, ekonomik ya da sosyal faktörler de belirleyici olabilir (Acar, 2020; Çeti \& Ünlüören, 2019). Bu nedenlerle turizm sektöründe herhangi bir güvenlik endişesi bulunması durumunda turizm hareketi bundan doğrudan olumsuz bir şekilde etkilenir. Bu etkilenmenin derecesi destinasyonun diğer özellikleri ile de birleşir ise orada bir kriz ortamı doğabilir. Bu kriz ortamını doğuran nedenlerden biri de salgın hastalıklardır. Geçmiş dönemde kuş gribinden ebolaya kadar ortaya çıkan çeşitli hastalıklar turizmi olumsuz etkilemişler, etki derecesi değişen krizler ortaya çıkarmışlardır. Bu krizlerin en belirgin sonucu olarak turizm destinasyon taleplerinde ciddi düşüşler yaşanmış ve sektör bu durumdan zarar görmüştür. Örnek olarak şekil 2 incelendiğinde dünyada gelişmekte olan ülkelerde pandemi nedeniyle turist girişlerindeki azalmanın \% 17 ila \% 90 arasında değiştiği görülmektedir. Bu azalmanın derecesi aynı zamanda ülke ekonomilerini de değişen oranlarda etkilemiş, Türkiye açısından yaklaşık \% 73'lük bir kayıp yaşanmıştır. Dünya'da Sri Lanka, Şili, Bolivya, Kazakistan ve Kenya gibi ülkeler Türkiye ile benzer oranlarda pandemiden etkilenen ülkeler olmuştur. Pandemiden en az etkilenen ülkelerden olan Madagaskar bunu temelde izole bir ada ülkesi olmasına borçludur. Pandemiden en az etkilenen 
diğer ülke olan Laos'ta da turizmin en hızlı büyüyen sektör olduğu ve Laos'un kırsal kalkınmayı gözeten ciddi ekoturizm yatrımları bulunan bir ülke olduğu bilinmektedir.

Covid 19 pandemisi dünya tarihinde turizmi derinden etkileyen salgınlardan biri olmuştur (WTTC, 2020). Geçmişteki krizlere oranla çok daha büyük bir kriz ortamı doğurmuştur. Covid 19 zaman-mekân sıkışması olarak da ifade edilebilen küreselleşmeyi de durdurmuştur. Hatta durdurmakla kalmayıp bunu tersine çevirmiştir (Niewiadomski, 2020). Nitekim küresel çapta sürdürülegelen seyahat ve turizm faaliyetleri durmuştur. Sonraki süreçte bildiğimiz turizm artık ortadan kalkmıştır. Ancak durum böyle olsa da küreselleşme barındırdığı dinamiklerle yeniden turizmin canlandırılması ve geliştirilmesi için elverişli firsatlar sunmaktadır.

Turizmin politik, ekonomik, psikolojik, sosyo-ekonomik ve çevresel etkileri Covid 19 ile birlikte daha fazla tartışılmaktadır. Artık dünyada Covid 19 sonrası dönemde insanların seyahat etmelerinin, birbirleriyle ve çevreleriyle karşılaşmalarının biçimleri dahi değişecektir. Tüm dünyada bu kapsamda sürdürülebilirliğin iş birliğine dayalı bölgesel yaklaşımlar üzerinde çalışılmaktadır (Lew vd., 2021). Yapılan araştırmalar bunun bir şekilde sağlanabileceğini göstermektedir. Covid 19 tüm bu süreci hazırlayan, hızlandıran ve dönüştüren; belki de sürdürülebilir kılacak olan küresel bir aktör olarak görünmektedir.

Turizm sektörü insan gücünün, insan etkileşiminin oldukça yoğun olduğu bir sektördür. Covid 19 pandemisi sektör üzerinde getirdiği ciddi etkiler ile birtakım değişimler dönüşümler gelişmesini zorunlu kılacaktır. Bu yönde geleceğe dönük bazı küresel turizm senaryoları öngörülmektedir (Şekil 4). Ancak burada önemli olan sektörün gelecekte turizmin geçireceği bu dönüşüme ne derece hazırlıklı olduğu; gelecekte ortaya çıkacak benzer salgın krizlerinde ne derece dayanıklı olacağı, ne tür adaptasyonlar ve kabiliyetler geliştireceği meselesidir. Covid 19 bu anlamda turizm sektörünü bir dayanıklılık testine tabi tutmuştur. Sektör bu testten eksikliklerini kapatarak, yeni uyum stratejileri geliştirerek daha güçlenmiş halde çıkabilir. Tersi bir durum sektörün geleceğinin tehlike altında olduğu anlamına gelecektir. Bu nedenle Covid 19 pandemisi tüm dünyaya 21. yüzyılda "turizmin nasıl yapılmaması" gerektiğini göstermiştir.

Williams ve Horodnic'e göre turizmde sürdürülebilir kalkınma vizyonunun uygulanması, özellikle son yıllarda büyük ilgi uyandırmıştır (Williams \& Horodnic, 2021). Bunun yanı sıra Ertuna ve arkadaşları turizm alanında sürdürülebilir bir vizyonun uygulanmasına ilişkin araştırmaların çok kapsamlı olmadığına işaret ederek, bu tür araştirmalara duyulan ihtiyacı vurgulamışlardır (Ertuna vd., 2019). Turizmin geleceğinin nasıl etkileneceği ya da şekilleneceği konusunda ciddi korkular vardır. Bu korkuların temelinde Covid 19 krizinin etkisiyle ortaya çıkan yeni durumlara daha dayanıklı çözümler üretmek amacıyla sürdürülen yaklaşımların, sürdürülebilirlikten ziyade "dayanıkılık" ana fikri üzerine kurgulanıyor olması endişesidir. Gelecekte turizm daha sürdürülebilir olmaktan ziyade daha ekonomik mi olacaktır? Bu yönde bir kayma olup olmayacağı zamanla netleşecektir. Bununla birlikte sürdürülebilirliğin, daha fazla turizm firsati sunan ve insan sermayesini kullanan daha temiz bir doğal çevre sağlayacağı; bu sayede turizm endüstrisinin restore ve konsolide edileceği ile ilgili görüşler de bulunmaktadır (Williams \& Horodnic, 2021).

\subsection{Pandemi Turizm İçin Fırsat mıdır, Tehdit midir?}

Geçmiş dönemde salgın hastalıkların, doğal afetlerin ve zaman zaman etkili olan krizlerin turizm gelişimini olumsuz yönde et-

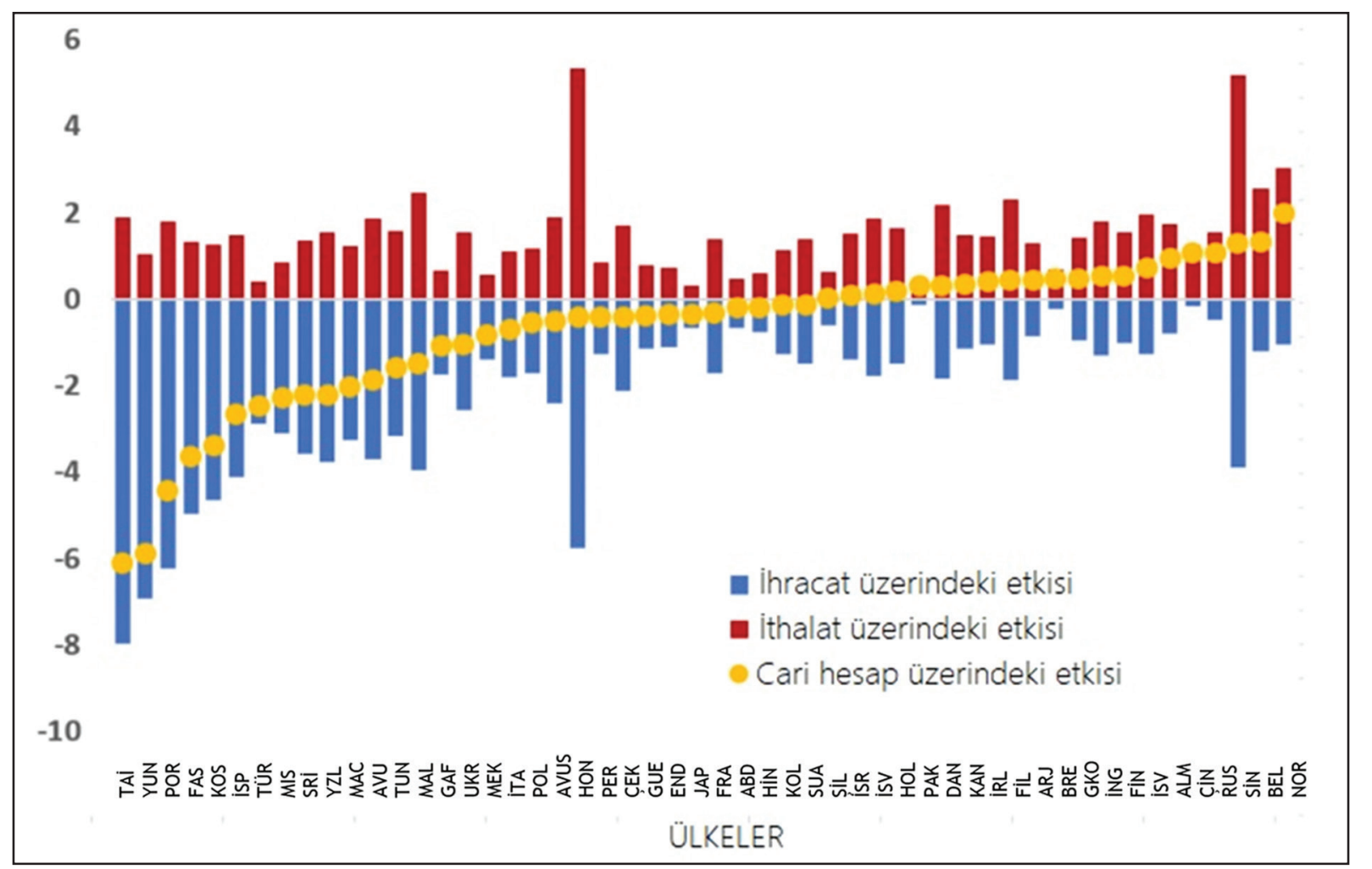

Şekil 3. Covid 19 pandemisinin ülkelere göre gösterdiği tahmini GSYH etkileri (\%) (Kaynak: WEF ve UNWTO, 2020'den değiştirilerek). Figure 3. Estimated GDP effects of the Covid 19 pandemic by country (\%) (Source: Modified from WEF and UNWTO, 2020). 
kilediği bilinmektedir. Bu olumsuz faktörlerin süresi, şiddeti ve ortaya çıkış şekli etki derecesi üzerinde doğrudan belirleyici olabilmektedir. Çalışmanın literatür taraması kısmından da anlaşılacağı üzere Covid 19 pandemisinden daha önce meydana gelen salgın hastalıkların özellikle bölgesel düzeyde turizmi olumsuz yönde etkilediği görülmektedir. Örneğin geçmişte 2003 ve 2012 yıllarında meydana gelen SARS ve MERS bu tür etkiler gösteren salgınlar arasındadır.

Pandemi ile beraber artk turizmde köklü birtakım değişimler yaşanmaya başlamıştır. Gelecekte de bu değişimlerin devam etmesi öngörülmektedir. Pandeminin öğrettiklerinden sonra artk turizmde uygulanan sosyal mesafe kuralları gereği kitle turizmi pratiklerinin terkedilmesi gündeme gelmiştir. Kalabalık oteller, kalabalık plajlar, kalabalık havuzlar artık turizmde yer bulamayabilir. Her şey dahil otellerin yerine turizmin arthk daha yerelleştiği ve bireyselleştiği yeni sürdürülebilir yaklaşımlar ön plandadır. Gelecekte turist tercihlerinin bu yönde gelişeceğini tahmin etmek güç değildir. Pandeminin seyri, etki süresi ve etki alanındaki güncel gelişmelere bağlı olarak birtakım değişiklikler yaşanacak olsa da turizm sektörünün bu gelişmelerden az ya da çok bir şekilde etkileneceği bir gerçektir. Bu durum her ne kadar ilk bakışta olumsuz bir yansıma olarak görülse de her krizin turizm sektörüne yeni şeyler öğrettiği, yeni kabiliyetler, adaptasyonlar ve kaçış yolları gösterdiği unutulmamalıdır. Bu anlamda Covid 19 krizi turizm sektörünün direncini, dayanıklıığını arttracaktır. Turizmin daha dirençli, güçlü ve rekabet edebilir yapısı alınacak önlemler ile de desteklenerek yeni firsatlar oluşturulabilir. Covid 19 krizi şu ana kadar turizmin başına gelen krizlerden bir tanesidir. Ne ilktir, ne de son olacaktr. Gelecekte de turizm benzer krizlerle karşılaşacaktır. Önemli olan bu krizleri atlatabilme kabiliyetleri geliştirmektir.

Covid 19 pandemisi turizm açısından nasıl değerlendirilmelidir? Pandemi turizm için bir firsat mıdır, yoksa tehdit midir? $\mathrm{Bu}$ konuda halihazırdaki durum incelendiğinde dünyanın birçok yerinde hala seyahat kısıtlaması ve turizm gelirlerinde gerileme görülmektedir. Turizm sektörü hala ciddi bir belirsizlik içerisindedir. Pandemi turizmde görülmemiş bir zorluk ve ha- reketsizlik doğurmuştur. Bu durum kısa zamanda ve bir anda üstesinden gelinecek bir durum değildir. Ancak tüm bunlara rağmen turizmde daha güvenli, öngörülebilir, sorumlu ve sürdürülebilir turizm modelleri oluşturulabilir. Pandemi tüm dünyaya turizmin doğa, kültür, iklim ve ekonomi ile ne derece hayati ilişkiler kurduğunu; sektörün hayatımızdaki yerinin neye karşılık geldiğini ve turizmin neden daha iyi yönetilmesi gerektiğini öğretmesi ve bunun iyice anlaşılması açısından önemli firsatlar sunmaktadır. Bu firsatların ne şekilde değerlendirileceği konusu turizm için hayati bir konu olarak dikkat çekmekte ve turizmin gelecekteki varlığını doğrudan ilgilendirmektedir.

Covid 19 pandemisinin 21. yüzyılda ortaya çıkardığı kriz şüphesiz başta sağlık sektörü olmak üzere ekonomik açıdan da tüm dünya ülkelerini etkiledi. Tüm dünyada pandemi turizm talebinin gelişimini önemli ölçüde etkileyen yerel ve uluslararası kısitlamalar nedeniyle turizm endüstrisine önemli zorluklar getirdi. Kriz aynı zamanda turizmin sürdürülebilirliği üzerindeki etkileri konusunda da ciddi bir tartş̧ma başlatt. Covid 19 krizi diğer krizler gibi turizm endüstrisinin daha sürdürülebilir hale gelmesi için bir firsat olabilir miydi? Bu konuda Muller, Covid 19 pandemisinin "belki de hayatta bir kez karşılaşılabilecek bir firsat" olabileceğini öne sürmektedir (Muller, 2020). Yine buna benzer şekilde yapılan bazı çalışmalarda "sürdürülebilirlik açısından bir krizin turizm endüstrisi için çok ihtiyaç duyulan bir şok dalgası" olduğu yönünde görüşler savunulmuştur (Nicola vd., 2020; Muller, 2020; Varzaru vd., 2021). Bu tespitler ışığında değerlendirildiğinde turizm aktörlerinin bu derin krizden yararlanabilecekleri, krizlerle ve ortaya çıkardığı etkilerle baş etmeyi öğrenebilecekleri ve bu sayede daha dayanıklı ve sürdürülebilir faaliyetler/işletmeler oluşturabilmek için yeni stratejiler geliştirebilecekleri ortaya çıkmaktadır. Hükümetler düzeyinde ise kriz ve öğrettikleri turizmde sürdürülebilir davranmayı destekleyen ve teşvik eden özel politikalar tasarlamak için bir firsat anlamına gelmektedir.

Varzaru ve arkadaşlarına göre Covid 19'un yarattğı sağlık krizi ve ekonomik krizin doğası, turizm endüstrisi için hem faaliyetlerin yürütülmesi hem de sürdürülebilirliğin sağlanması açısından benzeri görülmemiş birçok zorluk getirmiştir. Sürdü-

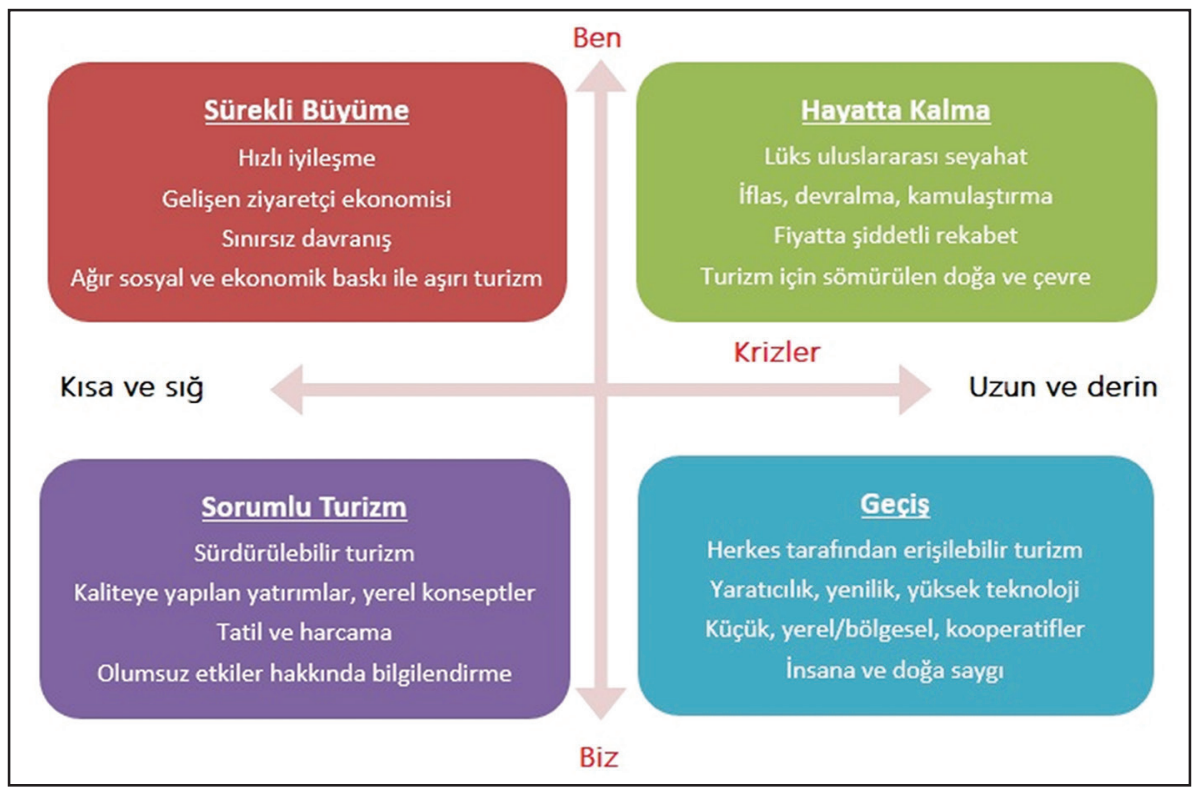

Şekil 4. Covid 19 sonrası dönemde 2025'te küresel turizm senaryoları (Kaynak: ETFI, 2021'den değiştirilerek). Figure 4. Global tourism scenarios in 2025 in the post-covid 19 era (Source: Modified from ETFI, 2021). 
rülebilir bir vizyon uygulamaya yönelik araştırmalar genellikle turizm endüstrisine özgü operasyonlara ve bireysel faaliyetlere odaklanırken, Covid 19'un yarattğı sağlık krizi ve ekonomik kriz, turizmde sürdürülebilirliği analiz etmek için derin etkileri olan tüm faaliyetleri ve süreçleri etkilemiştir. Turizm endüstrisi her zaman doğal afetlerden veya sağlık krizlerinden etkilenmiştir, ancak etkileri günümüze dek yerel düzeyde kalmış ve bunlarla mücadele edilebilmiştir. Covid 19 krizinin küresel doğası ise tüm sektörleri sistematik düzeyde derinden etkileyen bir domino etkisine neden olmuştur. Bu nedenle Varzaru ve arkadaşlarına göre bu etkilerle mücadele artık bireysel ya da yerel önlemlerle yapılamaz. Krizi daha iyi yönetebilmek için sistematik bir yaklaşıma ihtiyaç vardır. Ayrıca sağlık krizini daha iyi yöneten gelişmiş ülkelerde Covid 19 krizinin turizm üzerinde olumlu etkileri de gözlemlenmiştir. Sınır ötesi trafik kısıtlamaları göz önüne alındığında, turistlerin ulusal turizmi olumlu yönde etkileyecek yerel tesisleri seçecekleri öngörülmektedir. Sağlık krizinden ciddi şekilde etkilenen ve ağırlıklı olarak uluslararası turizme bağımlı olan az gelişmiş ülkelerde ise turizm endüstrisinde keskin bir düşüş yaşanmaktadır (Varzaru vd., 2021). Covid 19 krizine yönelik küresel anlamda sistematik bir yönetim modeli geliştirmek ve bu konuda üzerinde fikir birliğine varılmış bir küresel yaklaşım sergilemek turizm sektörünün ve çalışanlarının hayatta kalmaları açısından gerekli görülmektedir.

\section{Sonuç}

Yapılan araştırmalar turizm sektörünün geçmişten günümüze başta salgın hastalıklar olmak üzere birçok sorunla, krizle karşılaşt̆ğını göstermektedir. Bu krizlerin ortaya çıktıkları bölgeleri derinden etkiledikleri bilinse de küresel anlamda Covid 19 kadar geniş bir yayılıma sahip olmadıkları da bilinmektedir. Bu anlamda Covid 19 gerek ortaya çıktıktan sonraki yayılım hızı ve gerekse de yayıldığı coğrafya göz önüne alındığında geçmişteki örneklerinden farklılaşmaktadır.

Covid 19 pandemisi ortaya çıktıktan sonra Covid vakaları tüm dünyaya hızlı bir biçimde yayılmış ve ülkeleri ciddi bir çıkmaza sokmuştur. Bu çıkmaz ülkelerin sıkı tedbirler alması ile pandemi ilanına kadar gitmiştir. Devamında uluslararası hareketlilik nerdeyse tamamen durmuş ve hemen hemen tüm ülkeler sınırlarını kapatarak kendi vatandaşlarını koruma altına almışlardır. Çeşitli önlemler ve uygulamalar yürürlüğe konulmuş, Covid 19'un getirdiği sosyal, kültürel, ekonomik ve psikolojik olumsuzluklar en aza indirilmeye çalışılmıştır. Turizm sektörünün de aralarında olduğu bazı kırılgan sektörler en ciddi olumsuzlukların ve krizlerin yaşandığı sektörlerin başında gelmiştir.

Dünya açısından önemli bir geçim sektörü olan turizmin temelde pandemiden ağır şekilde etkilendiği, zarar gördüğü yadsınamaz bir gerçektir. Pandeminin dünya genelindeki seyrinin artması turizmdeki düşüşleri hızlandırmış ve derinleştirmiştir. Bu etki özellikle 2020 yılı başından itibaren kendini göstermeye başlamış, pandeminin yaygınlaşmasıyla beraber turizm faaliyetlerine katılmada önemli düşüşler yaşanmasına sebep olmuştur. Günümüzde hala pandemi turizmi etkilemeye devam etmektedir. Bu etki dünya genelinde hükümetlerin iç turizme ağırlık vermesi ve çeşitli turizm planlamaları ile kısmen azaltılmaya çalışılmıştır. Ancak bu çalışmalar yeterli olmamıştır. Hükümetler dünya genelinde Covid 19'un sebep olduğu bu krize nasıl yanıt vermeleri gerektiğini hala tam olarak belirleyeme- miştir. Alınan acil önlemler kapsamında kimi ülkelerde sektöre hükümetler tarafindan nakdi destekler sağlanmış, turizm işletmeleri korunmaya çalışılmıştır.

Pandemi neden olduğu karantinalar, kısıtlamalar ve uluslararası seyahat sınırlamaları ile turizm sektörü için ciddi ekonomik sonuçlar doğurmuştur. Bu ekonomik sonuçlar uluslararası turist varışlarının sayısının bir önceki yıla göre 3 kattan daha fazla azalması şeklinde kendini göstermiştir. Bu düşüşün doğrudan etkileri kadar özellikle dolaylı etkilerinin daha yıkıcı olacağı düşünülmektedir. Nitekim özellikle iş gücü, sermaye, mal ve hizmetlere olan talep eksikliğinin birçok sektörde olumsuz etkileri artarak devam etmektedir.

Dünya'da bazı ülkelerde pandemi yeşil ve sürdürülebilir turizm için bir firsat olarak değerlendirilmiş, bu yönde gelecekte etkili ve kalıcı olabilecek uygulamalar ve politikalar belirlenmeye başlamıştir. Küresel ölçekte başta kitle turizm merkezleri olmak üzere birçok uluslararası turizm destinasyonu durumdan önemli oranda etkilenmiş, pandemi döneminde özellikle kırsal alanlara olan talep ve baskı artmıştir. Bu baskı beraberinde turizm destinasyonlarının da yönünü değiştirmiş, doğal alanlar yavaş yavaş birer turizm destinasyonuna dönüşmeye başlamıştır. Bu durum başlı başına araştırılması gereken önemli bir sorundur. Zamanla aşı çalışmalarının başarıyla sonuçlanması ile özellikle iç turizmde yavaş yavaş hareketlenmeler başlamış, ancak yeterli canlanma henüz sağlanamamıştır.

Yapılan araştırmalar turizmin eski haline dönmesinin uluslararası düzeyde bir güven iklimi oluşmasıyla da yakından ilgili olduğunu göstermektedir. Çünkü turistler ancak güvende olduklarını hissettikleri an turizme katılmaya başlayabilirler. Bu süreçte iç turizm hareketlerinin desteklenmesi küresel anlamda turizmin ayağa kalkması için başlangıç çalışmaları olarak kabul edilebilir. Ancak bu yeterli değildir. Ülkeler arasındaki iş birliği çalışmaları da turizme katkı sağlayacaktır.

Yapılan araştırmalara göre pandeminin dünyada turizmi en çok etkilediği yerlerin başında Asya-Pasifik bölgesi ve Amerika kıtası gelmektedir. Sadece hava ulaşımı kaynaklı turizm zararlarının 80 milyar doları aşthğı ifade edilmektedir. Yaşanan bu pandemi krizi turizmde çok yönlü sorgulamaları da beraberinde getirmiştir. Özellikle uluslararası kitle turizmi destinasyonları bu krizden en çok etkilenen alanlar olmuştur. Bu alanlar hızla değer kaybetmiş, milyarlarca dolar zarar ortaya çıkmış, kırsal alanlara ve hizmetlere olan taleplerde adeta patlama yaşanmıştır. Bu noktada söz konusu küresel kriz hali turizmin geleceğini düşünmek ve planlamak için iyi bir firsat olabilir mi? Elbette olabilir. Dünya turizm aktörlerinin bunu destekleyen ifadeleri mevcuttur. Günümüzde turizm aktörlerinin ve hükümetlerin aldığı/alacağı önlemler şüphesiz geleceğin turizminin inşa edilmesinde önemli role sahiptir. Bu süreçte turizmde arthk bundan sonraki dönemde pandeminin var olacağı gerçeği kabul edilmeli ve bu yönde kısa, orta ve uzun vadeli turizm politikaları belirlenmelidir. Yaşanan kriz turizmdeki politikaların ve yaklaşımların daha sağlam, sürdürülebilir ve esnek olması noktasında bir öğretici ve hatırlatıcı olmalıdır.

Sonuç olarak pandeminin turizme olan etkisi henüz tam anlamıyla ortaya konulmuş değildir. Ancak pandeminin sona erdiği düşünüldüğünde turizmde artık çevreyi korumanın ve yerel istihdamı sağlamanın daha önemli olacağı düşünülmek- 
tedir. Bu dönemde turizm ve yerellik önemli iki unsur olarak varlığını sürdürecek ve turizmin yapılanması bu eksende daha güçlü gelişecektir. Turizm stratejilerinden biri olan ekoturizmin baskın hale geleceği, turizmde buna dair yeni niş ve destinasyonlar oluşacağı öngörülmektedir. Temassız hizmet alma noktasında turizmde teknolojinin daha çok yer bulacağı ve dijital teknolojiler içeren turizm yatırımlarının yapılacağı olasıdır. En önemli noktalardan biri de turist tercihleri ve davranışlarındaki muhtemel değişikliklerden sonra bazı ülkelerin tam anlamıyla turizme dayalı olan ekonomik yapısı etkilenecek ve bu ülkeler ekonomik varlığını sürdürebilmek için turizmden farklı ya da turizmin yanında başka yeni kazanım alanları keşfetmek zorunda kalacaklardır. Bu durum bu ülkelerin turizm dışındaki diğer sektörlere de yatırım yapmak zorunda kalacakları anlamına gelmektedir. Sonuç itibariyle turizmin eski parlak ve canlı günlerine dönmesi zaman alacaktır ancak bu durum sadece pandemiyle değil, uluslararası gelişmelerle de yakından ilgilidir. Önümüzdeki süreçte küresel ölçekte turizmde pandeminin etkilerini en aza indirebilmek için ülkeler turizmde yeni yol ve yöntemler aramaya devam edeceklerdir.

\section{Kaynakça}

Acar, Y. (2020). Yeni koronavirüs (Covid-19) salgını ve turizm faaliyetlerine etkisi. Güncel Turizm Araşttrmaları Dergisi, 4, (1), 7-21. https://doi.org/10.32572/guntad.703410.

Aharon, D., Arie, J., Cohen, E., Tzur, J., \& Qadan, M. (2021). Covid-19, government measures and hospitality industry performance. Plos One, Vol:16, https://doi.org/10.1371/journal.pone.0255819.

Blake, A., \& Sinclair, M. T. (2003). Tourism crisis management. Annals of Tourism Research, 30(4), 813-832.

Çeti, B., \& Ünlüönen, K. (2019). Salgın hastalıklar sebebiyle oluşan krizlerin turizm sektörü üzerindeki etkisinin değerlendirilmesi. AHBVÜ Turizm Fakültesi Dergisi, 22 (2), 109-128.

Çetin, G., \& Göktepe, S. (2021). Covid 19 pandemisinin turizm endüstrisi üzerindeki etkileri. iü iktisat Fakültesi Dergisi, İstanbul, https://doi.org/10.26650/B/SS46.2020.005.06.

ETFI (European Tourism Futures Institute). (2021, 22 November). Reports. URL: https://www.cbi.eu/market-information/tourism/ trends

Findlater, A., \& Bogoch, I. (2018). Human mobility and the global spread of infectious diseases: a focus on air travel. Trends in parasitology, 34(9), 772-783.

Fuste-Forne, F. and Michael, N. (2021). Limited tourism: travel bubbles for a sustainable future. Journal of Sustainable Tourism, 1-18, https://doi.org/10.1080/09669582.2021.1954654.

Gürsoy, D., Sarışık, M., Nunkoo, R., \& Boğan, E. (2021). Covid-19 and the hospitality and tourism industry. Edward Elgar Publishing, 400 pages, ISBN:9781800376236, UK.

Hall, C., Prayag, G., Fieger, P., \& Dyason, D. (2020). Beyond panic buying: consumption displacement and Covid-19. Journal of Service Management, https://doi.org/10.1108/JOSM-05-2020-0151.

Higgins-Desbiolles, F. (2020). Socialising tourism for social and ecological justice after Covid-19. Tourism Geographies. 22, https:// doi.org/10.1080/14616688.2020.1757748.

Hudson, S. (2020). Covid-19 and travel: Impacts, responses and outcomes. Goodfellow Publishers, ISBN: 9781911635703 (eBook), https://doi.org/10.23912/9781911635703-4387.
Karakaş, M. (2020). Covid-19 Salgınının çok boyutlu sosyolojisi ve yeni normal meselesi. Istanbul Üniversitesi Sosyoloji Dergisi, https://doi.org/10.26650/SJ.2020.40.1.0048.

Kervankıran, İ., \& Bağmancı, M. (2020). Bildiğimiz turizmin sonu mu? Covid-19'un Türkiye'deki turizm hareketliliğine etkisi. Türk Coğrafya Dergisi, 76, 19-32.

Lew, A., Cheer, J., Brouder, P., \& Mostafanezhad, M. (2021). Global tourism and Covid-19: Implications for theory and practice. Routledge, 1st Edition. 306 pages. ISBN: 9781032121369.

Muller, T. (2021). Why the Corona Virus Crisis Is a Unique and Once in a Lifetime Opportunity for Destinations and the Tourism Industry. https://voyagesafriq.com/2020/03/23/why-the-corona-virus-crisis-is-a-unique-andonce-in-a-lifetime-opportunity-for-destinations-and-the-tourism-industry

Newsome, D. (2020). The collapse of tourism and its impact on wildlife tourism destinations. Journal of Tourism Futures, 7, (3), 295302. https://doi.org/10.1108/JTF-04-2020-0053.

Nicola, M., Alsafi, Z., Sohrabi, C., Kerwan, A., Al-Jabir, A., Iosifidis, C., Agha, M., \& Agha, R. (2020) The Socio-Economic Implications of the Coronavirus Pandemic (COVID-19): A Review. International Journal of Surgery, 78, 185-193. https://doi.org/10.1016/i. ijsu.2020.04.018

Niewiadomski, P. (2020). Covid-19: From temporary de-globalisation to a re-discovery of tourism?. Tourism Geographies, 22(3), 651656, https://doi.org/10.1080/14616688.2020.175774.

Prideaux, B., Thompson, M., \& Pabel, A. (2020). Lessons from covid-19 can prepare global tourism for the economic transformation needed to combat climate change. Tourism Geographies, 22(3), 667-678. https://doi.org/10.1080/14616688.2020.1762117.

Rogerson, C. M., \& Rogerson, J. M. (2020). Covid-19 Tourism impacts in South Africa: Government and industry. GeoJournal of Tourism and Geosites, 31 (3), Pages: 1083-1091. https://doi. org/10.30892/gtg.31321-544.

Seyfi, S., Hall, C., \& Shabani, B. (2020). Covid-19 and international travel restrictions: The geopolitics of health and tourism. Tourism Geographies Studies. https://doi.org/10.1080/146166 88.2020.1833972.

United Nations Conference on Trade and Development. (2021). Covid 19 and tourism: An update. United Nations Conference on Trade and Development Report. 23 pages, Switzerland. https:// unctad.org/system/files/official-document/ditcinf2021d3 en $0 . p d f$

UNWTO. (2020). International tourism trends report. WTO (WorId Tourism Organisation) 2020 edition, Madrid https://doi. org/10.18111/9789284422456.

Varzaru, B., Bocean, C. and Cazacu, M. (2021). Rethinking Tourism Industry in Pandemic COVID-19 Period. Sustainability. 13.

Williams, C. and Horodnic, I. A. (2021). Tackling Undeclared Work in the Tourism Sector. European Plaform Tackling Undeclared Work (EPTU), URL: https://ec.europa.eu/social/BlobServlet=22868\&langld=en

WEF (World Economic Forum). (2020). Report. https://www.weforum.org/agenda/covid19-coronavirus-tourism-economv-gdp

WTTC (2020). Coronavirus Brief April 2020. https://wttc.org/en-us/ COVID-19/MemberHub, E.T. 